\title{
Calcium-Sensitive Particulate Guanylyl Cyclase as a Modulator of cAMP in Olfactory Receptor Neurons
}

\author{
Cheil Moon, ${ }^{1}$ Parham Jaberi, ${ }^{1}$ Annie Otto-Bruc, ${ }^{3}$ Wolfgang Baehr, ${ }^{5}$ Krzysztof Palczewski, ${ }^{3,4}$ and \\ Gabriele V. Ronnett ${ }^{1,2}$ \\ Departments of ${ }^{1}$ Neuroscience and ${ }^{2}$ Neurology, Johns Hopkins University School of Medicine, Baltimore, Maryland \\ 21205, Departments of ${ }^{3}$ Ophthalmology and ${ }^{4}$ Pharmacology, School of Medicine, University of Washington, Seattle, \\ Washington 98185, and ${ }^{5}$ Moran Eye Center, University of Utah Health Science Center, Salt Lake City, Utah 84132
}

\begin{abstract}
The second messengers cAMP and inositol-1,4,5-triphosphate have been implicated in olfaction in various species. The odorant-induced cGMP response was investigated using cilia preparations and olfactory primary cultures. Odorants cause a delayed and sustained elevation of cGMP. A component of this cGMP response is attributable to the activation of one of two kinetically distinct cilial receptor guanylyl cyclases by calcium and a guanylyl cyclase-activating protein (GCAP). cGMP thus formed serves to augment the cAMP signal in a cGMPdependent protein kinase (PKG) manner by direct activation of
\end{abstract}

Olfactory signal transduction is initiated when odorants interact with specific receptors on cilia (Rhein and Cagan, 1980). Receptors couple to a G-protein, which activates adenylate cyclase (Pace et al., 1985; Sklar et al., 1986; Breer et al., 1990; Ronnett et al., 1993; Jaworsky et al., 1995). cAMP levels increase and open a cyclic nucleotide-gated channel, resulting in an influx in $\mathrm{Na}^{+}$ and $\mathrm{Ca}^{2+}$ (Nakamura and Gold, 1987; Firestein and Werblin, 1989). Odorants also cause an elevation of inositol-1,4,5trisphosphate $\left(\mathrm{IP}_{3}\right)$; however, the role of $\mathrm{IP}_{3}$ is uncertain and may vary between species (Boekhoff et al., 1990, 1994; Ronnett et al., 1993).

cGMP is also implicated in the odorant response, although its generation is more complex. cGMP is produced by two different classes of enzymes (Garbers, 1991; Garbers et al., 1994). Cytosolic (soluble) guanylyl cyclases are heterodimers activated by the binding of a gaseous messenger, such as nitric oxide (NO) or carbon monoxide $(\mathrm{CO})$, to the heme moiety in the enzyme (Furchgott and Zawadzki, 1980; Brune et al., 1990; Gräser et al., 1990; Schmidt, 1992; Murad, 1994). CO is produced by heme oxygenase (HO), which degrades heme into iron, $\mathrm{CO}$, and biliverdin (which is rapidly reduced to bilirubin) (Maines, 1988; Schmidt, 1992). There are two known isoforms of HO (Maines, 1988), of which HO-2 is expressed in neurons (Sun et al., 1990a,b;

\footnotetext{
Received Oct. 20, 1997; revised Dec. 30, 1997; accepted Feb. 12, 1998.

This research was supported by the W. M. Keck Foundation and National Institutes of Health Grants DC01704 and DC02979 to G.V.R., F32 DC00243 to C.M., EY08061 to K.P., and EY08123 to W.B., and awards from Research to Prevent Blindness, Inc. (RPB) to the Department of Ophthalmology at the University of Washington and the Department of Ophthalmology at the University of Utah. K.P. is the recipient of a Jules and Doris Stein Professorship from RPB. We thank Jackie Corbin and Daniel Storm for helpful discussions and review of data, Clark Riley for assistance in image processing, Helen Cho and Preston Van Hooser for technical assistance, and Lana Kramer for manuscript preparation and support.

Correspondence should be addressed to Gabriele V. Ronnett, Department of Neuroscience, Johns Hopkins University School of Medicine, Hunterian 803, 725 N. Wolfe Street, Baltimore, MD, 21205.

Copyright (C) 1998 Society for Neuroscience $\quad 0270-6474 / 98 / 183195-11 \$ 05.00 / 0$
}

adenylate cyclase. cAMP, in turn, activates cAMP-dependent protein kinase (PKA) to negatively regulate guanylyl cyclase, limiting the cGMP signal. These data demonstrate the existence of a regulatory loop in which cGMP can augment a cAMP signal, and in turn cAMP negatively regulates cGMP production via PKA. Thus, a small, localized, odorant-induced cAMP response may be amplified to modulate downstream transduction enzymes or transcriptional events.

Key words: olfaction; signal transduction; guanylyl cyclase; olfactory receptor neuron; cilia; protein kinase
Verma et al., 1993). The second class is receptor (particulate) guanylyl cyclases. They contain a transmembrane domain and are activated by extracellular ligands (Sun and Reis, 1992; Wong and Garbers, 1992; Yuen and Garbers, 1992; Drewett and Garbers, 1994; Garbers and Lowe, 1994) or by $\mathrm{Ca}^{2+}$ in the visual system (Koch and Stryer, 1988). A group of particulate guanylyl cyclases function in sensory transduction, and includes retina-specific retGC-1 (GC-E) and retGC-2 (GC-F), in photoreceptor cells (Dizhoor et al., 1994) and the pineal gland (Hayashi and Yamazaki, 1991; Yang et al., 1995). Their ligands, if any, remain unknown. In the retina, the rate of cGMP synthesis is regulated by $\mathrm{Ca}^{2+}$. During the light response, closure of cGMP-gated channels reduces $\mathrm{Ca}^{2+}$ influx, decreasing intracellular $\mathrm{Ca}^{2+}$. The fall in $\mathrm{Ca}^{2+}$ stimulates guanylyl cyclase and promotes recovery of the light response (McNaughton, 1990). The stimulation of retinal guanylyl cyclase by low $\mathrm{Ca}^{2+}$ is mediated intracellularly by guanylyl cyclase-activating proteins (GCAPs), a $23 \mathrm{kDa} \mathrm{Ca}^{2+}$. binding protein (Dizhoor et al., 1994; Gorczyca et al., 1994; Palczewski et al., 1994).

cGMP and its effectors are implicated in several aspects of olfaction. Although not found in mature olfactory receptor neurons (ORNs), NO synthase is highly and transiently expressed in developing and regenerating ORNs (Roskams et al., 1994). These data argue against a role for NO-mediated cGMP in odorsensitive signaling, but they suggest a function for $\mathrm{NO}$ in the activity-dependent establishment of connections in both developing and regenerating ORNs. HO-2, however, is highly expressed in mature ORNs, where it mediates cGMP production by the activation of soluble guanylyl cyclase (Verma et al., 1993). Olfactory neurogenic/maturation factors (Mahanthappa and Schwarting, 1993) cause a CO-dependent modulation of cGMP in primary cultures of ORNs (Ingi and Ronnett, 1995). cGMP is also reported to act at the cyclic nucleotide-gated channel to produce a form of adaptation (Leinders-Zufall et al., 1995, 1996). Re- 
cently, an olfactory guanylyl cyclase, GC-D, was cloned (Fulle et al., 1995), and its expression was localized to a subset of neurons (Fulle et al., 1995; Yu et al., 1997). Odorants also elevate cGMP levels in a slow and sustained manner in primary cultures of rat ORNs (Verma et al., 1993; Ingi and Ronnett, 1995) and in cilia (Breer et al., 1992), although it is unclear which type of guanylyl cyclase is responsible. These studies suggested that the odorantinduced cGMP response is not involved in initial signaling events but rather is involved in desensitization or in other longer term responses.

In this study, we characterize the olfactory cilial odorantinduced cGMP response. We demonstrate that there are at least two kinetically distinct cilial guanylyl cyclases. An odorantinduced cGMP response is mediated by a low $K_{\mathrm{m}}$ particulate guanylyl cyclase, which is regulated by $\mathrm{Ca}^{2+}$ and a GCAP-like protein, and phosphorylation. In turn, cGMP activates adenylate cyclase in a PKG-dependent manner, creating a secondary cAMP response that may function in modulating signal regulation.

\section{MATERIALS AND METHODS}

Cilia preparation. Cilia were prepared as described previously (Anholt et al., 1986) with modification. Briefly, male Sprague Dawley rats (125-150 gm) were killed by decapitation. Nasal turbinates were dissected, pooled, and washed in frog's Ringer's solution (112 mM NaCl, $3.4 \mathrm{~mm} \mathrm{KCl}, 2.4$ mm NaHCO $3,2 \mathrm{~mm}$ EDTA, $2 \mathrm{~mm}$ HEPES, pH 7.4) at $4^{\circ} \mathrm{C}$. The tissue was centrif uged at $5,000 \times g$ for $5 \mathrm{~min}$. The pellet was resuspended in 100 $\mathrm{mm} \mathrm{NaCl}, 30 \mathrm{~mm}$ Tris, $\mathrm{pH}$ 7.4. The bathing medium was supplemented with $\mathrm{CaCl}_{2}$ to a final concentration of $10 \mathrm{~mm}$, and agitated gently on an end-over-end shaker for $20 \mathrm{~min}$ at $4^{\circ} \mathrm{C}$. The deciliated epithelium was removed by centrifugation for $5 \mathrm{~min}$ at $1500 \times \mathrm{g}$. The supernatant containing the detached cilia was centrifuged for $15 \mathrm{~min}$ at $12,000 \times \mathrm{g}$, and the resulting pellet was washed twice in $3 \mathrm{mM} \mathrm{MgCl}_{2}, 1 \mathrm{~mm}$ EDTA, $10 \mathrm{~mm}$ Tris, $\mathrm{pH}$ 7.4. The final cilia pellet was resuspended in a small volume of $3 \mathrm{~mm} \mathrm{MgCl}_{2}, 1 \mathrm{~mm}$ EDTA, $10 \mathrm{~mm}$ Tris, $\mathrm{pH}$ 7.4. The concentrated rat cilia were aliquoted and stored at $-70^{\circ} \mathrm{C}$ before use.

Primary culture of ORNs. Cultures were prepared as described previously (Ronnett et al., 1991) with modification. The 1- to 2-d-old rat pups (100 per preparation) were killed by decapitation, and olfactory tissue was dissected and immediately placed in modified Eagle's medium (MEM) containing $4.8 \mathrm{gm} / 1$ of HEPES buffer, $\mathrm{pH} 7.4$, designated MEMAIR. The suspension was transferred twice through fresh MEM-AIR to minimize contamination and centrifuged at $700 \times g$ for $7 \mathrm{~min}$. After the supernatant was decanted, the tissue was minced to achieve fragments of $\sim 1 \mathrm{~mm}$ in size, resuspended in MEM-AIR, and centrifuged at $700 \times \mathrm{g}$ for $7 \mathrm{~min}$. Tissue was placed in $30 \mathrm{ml}$ of MEM-AIR containing $1 \%(\mathrm{w} / \mathrm{v})$ BSA, RIA grade (Sigma, St. Louis, MO), $1 \mathrm{mg} / \mathrm{ml}$ hyaluronidase (Sigma), $50 \mu \mathrm{g} / \mathrm{ml}$ dispase (Boehringer Mannheim, Indianapolis, IN), and incubated with agitation for $1 \mathrm{hr}$ at $37^{\circ} \mathrm{C}$. At the end of incubation, the cell suspension was centrifuged at $500 \times g$ for $5 \mathrm{~min}$. The supernatant was aspirated, and the cell pellet was resuspended in plating medium composed of MEM containing D-valine (MDV; Life Technologies, Gaithersburg, MD) containing 15\% (v/v) dialyzed fetal calf serum (dFCS; Life Technologies), 5\% (v/v) NU serum (Collaborative Research, Bedford, MA). After resuspension, cells were successively filtered through 50 and $10 \mu \mathrm{m}$ nylon mesh filters (Small Parts) to remove any remaining undigested clumps of cells and epithelial cells. Cells were plated at a density of $1 \times 10^{6}$ cells per $\mathrm{cm}^{2}$ into tissue culture dishes (Falcon) or Labtek tissue culture slides (Nunc, Naperville, IL) coated with MDV containing laminin at $25 \mu \mathrm{g} / \mathrm{ml}$ (Collaborative Research). Cultures were placed in a humidified $37^{\circ} \mathrm{C}$ incubator receiving $5 \% \mathrm{CO}_{2}$. On day 2 and every day thereafter, cells were fed with MDV containing $15 \%$ dFCS, gentamycin, kanamycin, NGF, and cytosine arabinoside. Two days before use, the medium was changed to a similar formulation with one-tenth the amount of NGF.

Bulbectomy. Adult Sprague Dawley rats were anesthetized with xylaket [25 ketamine $\mathrm{HCl}, 100 \mathrm{mg} / \mathrm{ml}$; $2.5 \%$ xylazine, $100 \mathrm{mg} / \mathrm{ml}$ (Rompun, A. J. Buck Inc.), and $14.2 \%$ ethanol in a solution of $0.9 \%$ saline] and fixed in a stereotactic apparatus during surgery. For unilateral bulbectomies, the right olfactory bulb was exposed via a partial dorsal craniotomy and was ablated by suction. Care was taken to avoid damage to the contralateral (left) olfactory bulb. The ablation cavity was filled with gelfoam to prevent invasion of frontal cortex into this cavity, which could provide an alternative target for regenerating olfactory axons. The skin above the lesion was then sutured, and animals were allowed to recover from anesthesia under a heat lamp. The degree of lesion was visually and microscopically verified. In all cases reported it was complete or supercomplete (extending into the olfactory peduncle). After recovery from anesthesia, rats were returned to the animal colony and maintained on a normal diet until they were killed at $3 \mathrm{~d}$, and 1, 2, and 3 weeks after bulbectomy.

Measurement of free $\mathrm{Ca}^{2+}$. To obtain the most accurate determination of free $\mathrm{Ca}^{2+}$, samples were measured against known commercially purchased solutions from Orion Instruments (Boston, MA) containing varying free $\mathrm{Ca}^{2+}$ concentrations (Jaworsky et al., 1995). These solutions were used to calibrate an Orion $\mathrm{pCa}$ meter. Standard curves were performed before each determination. Probably because of the extensive EDTA treatment during isolation, cilia do not alter the free $\mathrm{Ca}^{2+}$ concentration of the prepared buffers.

Cilia stimulation. To measure the odorant-induced cGMP response, isolated cilia were exposed to reaction buffer containing $200 \mathrm{mM} \mathrm{NaCl}, 10$ mM EGTA, $2.5 \mathrm{~mm} \mathrm{MgCl} 2,10 \mathrm{nM} \mathrm{CaCl}_{2}, 1 \mathrm{~mm} \mathrm{Mg-ATP,} 10 \mu \mathrm{M}$ GTP, $1 \mathrm{~mm}$ DTT, $0.5 \mathrm{~mm}$ IBMX, $50 \mathrm{~mm}$ MOPS, pH 7.4, with or without odorant at appropriate concentrations. Cilia were incubated with $0.5 \mathrm{mM}$ IBMX, a phosphodiesterase (PDE) inhibitor, for $15 \mathrm{~min}$. The reaction was terminated by the addition of trichloroacetic acid (TCA) at the final concentration of $6 \%$.

cGMP and cAMP determinations. Radioimmunoassay was performed as described previously (Ronnett et al., 1993; Jaworsky et al., 1995) with modifications. Incubations were quenched with $6 \%(\mathrm{w} / \mathrm{v})$ TCA. The quenched samples were collected on ice and spun for $5 \mathrm{~min}$ in a microfuge at $4^{\circ} \mathrm{C}$. The supernatant was collected and ether-extracted four times with anhydrous ether to remove TCA. cAMP was assayed with the Amersham ${ }^{125}$ I-labeled cAMP assay system; cGMP was assayed with the Amersham ${ }^{125}$ I-labeled cGMP assay system acetylation method.

Adenylate cyclase assays. Adenylate cyclase was assayed as described by Salomon (1979) with modifications. The isolated olfactory cilia (20 $\mu \mathrm{g} / \mathrm{ml}$ ) were stimulated for $1 \mathrm{~min}$ in reaction mixture containing $10 \mathrm{mM}$ Tris acetate, $\mathrm{pH} 7.6,5 \mathrm{~mm}$ magnesium acetate, $100 \mu \mathrm{M}$ ATP, $100 \mu \mathrm{M}$ GTP, $500 \mu \mathrm{M}$ cAMP, creatinine phosphate $(2 \mathrm{mg} / \mathrm{ml})$, creatine phosphokinase $(185 \mathrm{U} / \mathrm{ml})$, Tris-intracellular buffer $(150 \mathrm{mM} \mathrm{KCl}, 1 \mathrm{~mm}$ $\mathrm{MgCl}_{2}, 20 \mathrm{~mm}$ Tris-HCl, pH 7.4), and $\left[\alpha-{ }^{32} \mathrm{P}\right]$ ATP $(10 \mu \mathrm{Ci} / \mathrm{ml}) .8$ $\mathrm{Br}$-cGMP (1 mM) and isobutylmethoxypyrazine (IBMP; $0.1 \mu \mathrm{M}$ ) stimulation solutions were prepared simply by adding appropriate concentrations of these materials in reaction mixture. The reaction was terminated by adding quench solution containing $45 \mathrm{~mm}$ ATP, 2\% SDS, $1.3 \mathrm{~mm}$ cAMP, and ${ }^{3} \mathrm{H}$ cAMP $(0.2 \mu \mathrm{Ci} / \mathrm{ml})$. The quenched samples were boiled for 2 min at $100^{\circ} \mathrm{C}$ and cooled down on ice. The cooled samples were applied to Dowex columns and drained fully. The Dowex columns were washed once with double distilled (dd) $\mathrm{H}_{2} \mathrm{O}$, and then the samples were eluted by adding $2 \mathrm{vol}$ of dd $\mathrm{H}_{2} \mathrm{O}$. The collected samples were applied to alumina columns and allowed to drain completely. The alumina columns were eluted with $0.1 \mathrm{M}$ imidazole. Samples were counted on a Beckman LS6000SC scintillation counter.

Determinations of steady-state kinetics. Isolated rat olfactory cilia were incubated with various concentrations of GTP in the range of 0 to $10 \mathrm{mM}$ for $8 \mathrm{~min}$. The amount of produced cGMP was determined using a cGMP RIA kit (Amersham), as described in Materials and Methods.

To determine steady-state kinetics, Lineweaver-Burk analyses and Eadie-Hofstee analyses were performed. Because of curve fitting performed by Best-set analysis and verified manually, apparent $K_{\mathrm{m}}$ and $V_{\max }$ values were determined. All these values were determined from at least three independent experiments.

Expression and purification of bovine GCAP1 and GCAP2. GCAP1 was expressed in High Five cells $\left(2-3 \times 10^{8}\right)$ and purified using affinity chromatography on a G2 monoclonal antibody column (Gorczyca et al., 1995). Native or bacterially expressed bovine GCAP2 was affinity-purified using UW50 polyclonal antibody as described by Otto-Bruc et al. (1997).

Partial purification of particulate guanylyl cyclase. Olfactory particulate guanylyl cyclase was solubilized and purified by a single chromatography step on a GTP-agarose column (Hayashi and Yamazaki, 1991). Isolated olfactory cilia were incubated with solubilization buffer containing $30 \mathrm{~mm}$ Tris-HCl, pH 7.0, 1 mm DTT, $1 \mathrm{~m} \mathrm{KCl,} \mathrm{0.2 \%} \mathrm{Nonidet} \mathrm{P-40} \mathrm{(NP-40),} \mathrm{and}$ $0.1 \mathrm{~mm}$ phenylmethylsulfonylfluoride (PMSF) for $3 \mathrm{hr}$ on ice. The samples were centrifuged at $100,000 \times g$ for $1 \mathrm{hr}$. The supernatant was carefully recovered and dialyzed in $30 \mathrm{~mm}$ Tris-HCl, $\mathrm{pH}$ 7.0, 1 mM DTT, and $0.1 \mathrm{~mm}$ PMSF overnight at $4^{\circ} \mathrm{C}$. The buffer was changed four times 
during dialysis. The column was packed with GTP-agarose (Sigma) and prewashed three times with $30 \mathrm{~mm}$ Tris-HCl, $\mathrm{pH}$ 7.0, $3 \mathrm{~mm} \mathrm{MgCl}_{2}, 1 \mathrm{~mm}$ DTT, and $0.1 \mathrm{~mm}$ PMSF. The dialyzed sample was poured to the column and allowed time to bind to GTP-agarose resin. The column was washed three times with $30 \mathrm{~mm}$ Tris- $\mathrm{HCl}, \mathrm{pH} 7.0,3 \mathrm{~mm} \mathrm{MgCl}_{2}, 1 \mathrm{~mm}$ DTT, and $0.1 \mathrm{~mm}$ PMSF. Particulate guanylyl cyclase was eluted by elusion buffer containing $30 \mathrm{~mm}$ Tris- $\mathrm{HCl}$, pH 7.0, $3 \mathrm{~mm} \mathrm{MgCl}_{2}, 2 \mathrm{~mm}$ free GTP, $1 \mathrm{~mm}$ DTT, and $0.1 \mathrm{~mm}$ PMSF. To remove free GTP, the collected samples were dialyzed overnight in $30 \mathrm{~mm}$ Tris- $\mathrm{HCl}, \mathrm{pH} 7.0,3 \mathrm{~mm} \mathrm{MgCl}_{2}, 1 \mathrm{~mm}$ DTT, and 0.1 mM PMSF. The protein amount was determined spectrophotometrically. The purity of purified pGC was examined by silver staining using a commercial kit (Silver Stain Plus, Bio-Rad, Hercules, CA). The pGC activity was tested by cGMP RIA as described earlier.

In vitro phosphorylation. Phosphorylation reactions were performed according to the method of Steiner et al. (1992), with modifications. Partially purified particulate guanylyl cyclase was incubated with one of several protein kinases for $30 \mathrm{~min}$ at room temperature in a reaction buffer $(200 \mu \mathrm{l})$ containing $50 \mathrm{~mm}$ Tris- $\mathrm{HCl}$, pH 7.5, $10 \mathrm{mM} \mathrm{MgCl}_{2}, 0.4$ mM EGTA, $1 \mathrm{~mm}$ ATP, and $0.5 \mu \mathrm{Ci}\left[\gamma^{32} \mathrm{P}\right] \mathrm{ATP}$. Protein kinases were obtained from Promega (Madison, WI). For each protein kinase, appropriate stimulators were also added as described in figure legends. The reaction was stopped by the addition of the same volume of SDS sample buffer containing $100 \mathrm{~mm}$ Tris- $\mathrm{HCl}$ at $\mathrm{pH}$ 6.8, 2\% SDS, 10\% $\beta$-mercaptoethanol, and $20 \%$ glycerol. The samples were boiled and subjected to SDS-PAGE using a 10\% acrylamide gel. The gels were vacuum-dried and exposed to x-ray film. In all cases, the activity of the kinases was verified by incubation with substrate known to be specific for each kinase.

Antibodies. Anti-guanylyl cyclase antibody (1139) was produced against a peptide based on amino acids $880-896$ of GC-A (the sequence that is from the catalytic site; thus it is anticipated that it will react with most GCs) conjugated to bovine serum albumin, which was then injected into rabbits. Antibody 1139 was purified and characterized as described previously (Ingi et al., 1996) using a column packed with Affi-gel 10 linked to the peptide (Bio-Rad).

Anti-PKG antibody was a gift from Dr. J. D. Corbin (Vanderbilt University, Nashville, TN). This antibody is the affinity-purified antibovine lung type I $\alpha$ PKG IgG, and recognizes the type I $\alpha$ PKG and, in a limited manner, the type I $\beta$ PKG.

Anti-GCAP antibodies UW14 were raised in New Zealand white rabbits, and the antibodies were affinity-purified as described (Gorczyca et al., 1995). Rabbit anti-GCAP2 polyclonal antibodies (UW 50) were raised in New Zealand white rabbits and affinity-purified (Otto-Bruc et al., 1997).

Immunohistochemistry. Immunohistochemistry was performed as described previously (Roskams et al., 1994). Primary antibodies were detected using an avidin-biotin-peroxidase kit (Elite kit, Vectastain) and visualized with diaminobenzidine (DAB).

Gel electrophoresis and immunoblot analysis. SDS-PAGE was performed according to the method of Laemmli (1970) using 12\% polyacrylamide gels. The electrotransfer of proteins onto Immobilon-P (Millipore, Bedford, MA) was performed using a Hoeffer mini-gel system. For immunoblotting, membranes were blocked with a $3 \%(\mathrm{w} / \mathrm{v})$ gelatin in 20 $\mathrm{mm}$ Tris- $\mathrm{HCl}$ buffer, $\mathrm{pH} 8.0$, containing $150 \mathrm{~mm} \mathrm{NaCl}$ and $0.05 \%$ Tween-20, and incubated for 1-2 hr with primary antibody at a dilution of 1:10,000. A secondary antibody conjugated with alkaline phosphatase (Promega) was used at 1:5000 dilution. Antibody binding was detected using 5-bromo-4-chloro-3-indolyl phosphate and nitroblue tetrazolium.

Immunoblots were performed according to Laemmli (1970) and Towbin et al. (1979) with modifications. Total homogenates of adult rat isolated olfactory cilia $(200 \mu \mathrm{g})$ were solubilized in $1 \%$ $\beta$-mercaptoethanol and subjected to SDS-PAGE on a $10 \%$ gel. The separated proteins were transferred to nitrocellulose membrane (BA-S $83,0.2 \mu \mathrm{m})$, and the membrane was probed with primary antibody at the following concentrations: rabbit anti-guanylyl cyclase antibody 1139, 1:1000; rabbit anti-GCAP1, 1:10,000; rabbit anti-PKG, 1:5000. The secondary antibody was HRP-conjugated goat anti-rabbit immunoglobulin (Boehringer Mannheim) used at 1:10,000 dilution. The immunoblot was detected by chemiluminescence reagent (DuPont NEN, Wilmington, DE). The molecular sizes are indicated on the left side. Bands were visualized using the enhanced chemiluminescence (ECL, Amersham) reagents and exposing the blot to x-ray film (X-OMAT XAR, Kodak), or by alkaline phosphatase.

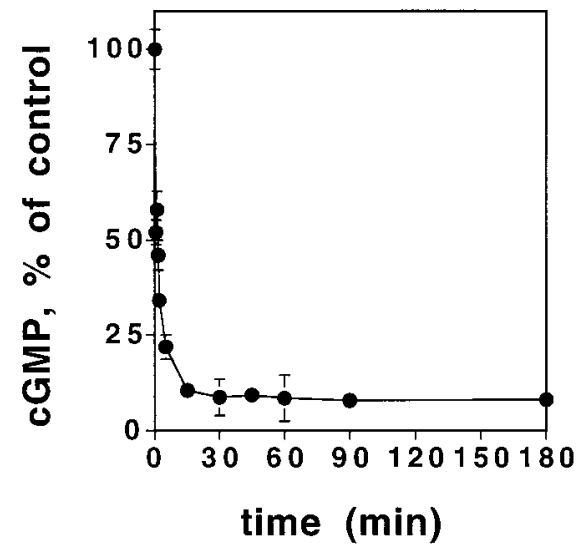

Figure 1. Time course of the effect of LY83583 on cGMP levels in primary cultures of olfactory neurons. Cells were isolated and plated as described in Materials and Methods. At zero time, $1 \mu \mathrm{M}$ LY83583 was added to cultures, and the amount of cGMP was determined by RIA at times thereafter. cGMP levels dropped rapidly but did not fall below $8 \%$ of control despite prolonged incubation.

\section{RESULTS}

\section{Characterization of the odorant-induced cGMP response}

To initially determine the contribution of each class of guanylyl cyclase to the ambient cGMP pool in ORNs, primary cultures of ORNs were incubated in the absence or presence of $1 \mu \mathrm{M}$ LY83583, an inhibitor of soluble guanylyl cyclase (Kawada et al., 1994). In the presence of LY83583, cGMP levels decreased rapidly but did not drop below $8 \%$ of control (Fig. 1). This result suggested that although a majority of the cGMP pool was contributed by soluble guanylyl cyclase activity, a consistent amount was generated by particulate guanylyl cyclase. A likely site for this activity is olfactory cilia.

Olfactory cilia can be separated from the olfactory epithelium by $\mathrm{Ca}^{2+}$ shock (Anholt et al., 1986). Odorant-induced second messenger responses, e.g., cAMP or $\mathrm{IP}_{3}$, are preserved in isolated olfactory cilia (Breer et al., 1990; Borisy et al., 1991; Boekhoff et al., 1994; Jaworsky et al., 1995). To investigate the olfactory cGMP response, rat olfactory cilia were incubated for varying times in a reaction buffer containing $0.5 \mathrm{~mm}$ isobutylmethylxanthine (IBMX, a phosphodiesterase inhibitor) and either a $0.1 \mu \mathrm{M}$ solution of the odorant isobutylmethoxypyrazine (IBMP) or solvent control. IBMP treatment resulted in a $330 \pm$ $12 \%$ (mean \pm SEM) increase in cGMP (Fig. $2 A$ ). The IBMPinduced cGMP response showed an initial delay of 15-30 sec and was sustained, lasting at least $10 \mathrm{~min}$. Cilia maintained in identical conditions but exposed to solvent control showed no such response (Fig. 2A). Other odorants showed similar cGMP responses (data not shown).

A dose-response curve for the effect of IBMP on cGMP levels demonstrated that the IBMP-induced cGMP response was saturable (Fig. 2B). This dose-response curve shares similarity to the odorant-induced cAMP responses obtained using olfactory cilia (Ronnett et al., 1993; Jaworsky et al., 1995). Saturable doseresponse curves were obtained for three other odorants, citralva, isovaleric acid, and D-carvone (data not shown). The use of IBMX (Beavo et al., 1970) in these assays suggested that this increase in cGMP production resulted from activation of a guanylyl cyclase, rather than inactivation of PDE. 

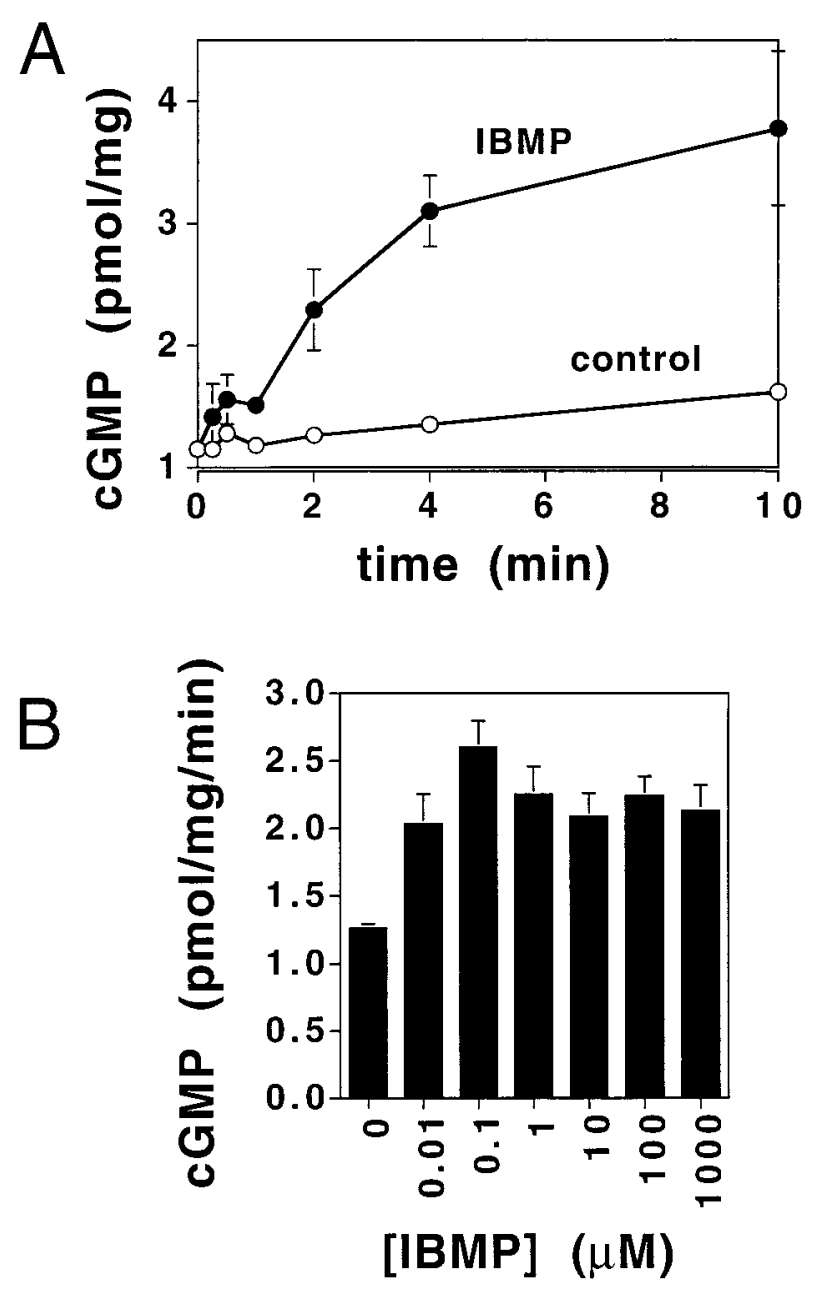

Figure 2. Time course for the cyclic GMP response to the odorant IBMP in rat olfactory cilia. $A$, The effect of IBMP on cGMP levels (presented as $\mathrm{pmol} / \mathrm{mg}$ protein) in rat olfactory cilia measured over time. O, Basal activity; $\bullet$, activity in the presence of $0.1 \mu \mathrm{M}$ IBMP. IBMX was included in the incubations. At each time point, duplicate samples were quenched with TCA as described in Materials and Methods, and the concentration of cGMP was determined by RIA. Results are averages of duplicates representative of five separate determinations. Error bars for control overlap with data points and thus are not visualized. $B$, Doseresponse curve for the effect of IBMP on cGMP levels in rat olfactory cilia. Isolated olfactory cilia were incubated with reaction mix containing various concentrations of IBMP for $2 \mathrm{~min}$. The reactions were quenched with TCA, and RIA was performed to determine cGMP levels. Results are averages of duplicates representative of three separate experiments.

\section{Identification of cilial guanylyl cyclase activities}

Because odorants could affect either a particulate or soluble guanylyl cyclase, cilia were incubated with reagents or ligands known to specifically activate each of these two enzymes. To determine whether a soluble guanylyl cyclase was activated, cilia were incubated with sodium nitroprusside (SNP), a potent NO donor that activates all guanylyl cyclases (Kowaluk et al., 1992) (Fig. 3). SNP (100 $\mu \mathrm{M})$ failed to augment cGMP levels, indicating that soluble guanylyl cyclase is not present in the olfactory cilia preparation and therefore cannot mediate this response. Although soluble guanylyl cyclase does exist in olfactory receptor neurons (Verma et al., 1993; Ingi and Ronnett, 1995), it is not retained during cilia isolation. To determine whether any ligands known to activate particulate guanylyl cyclases can activate the cilial enzyme, these ligands for particulate guanylyl cyclases were

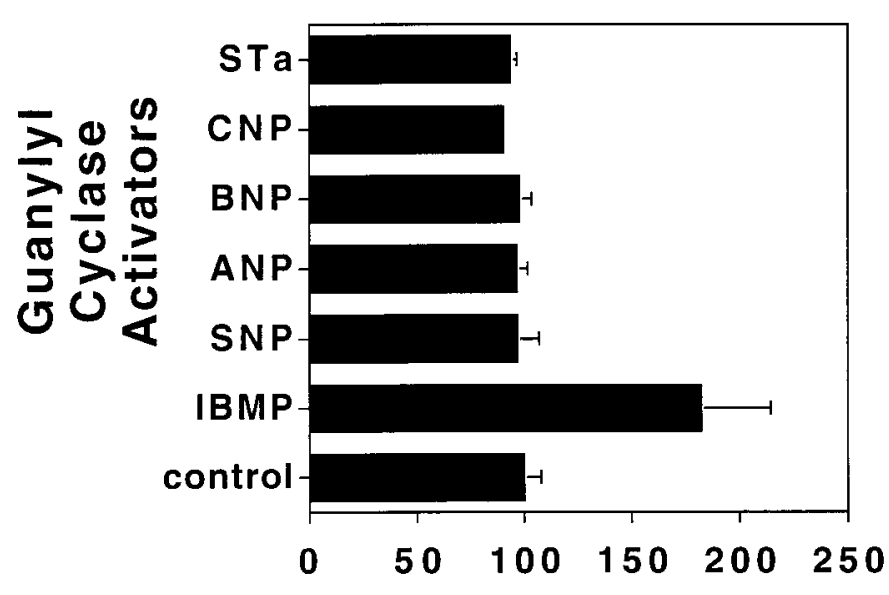

\section{cGMP (\% of control)}

Figure 3. Stimulation of guanylyl cyclase activity in rat olfactory cilia by known activators of guanylyl cyclases. Activators that were tested were 0.1 $\mu \mathrm{M} I B M P, 100 \mu \mathrm{M} S N P, 1 \mathrm{~mm} A N P, 0.1 \mathrm{~mm} B N P, 0.1 \mathrm{~mm} C N P$, and 0.1 $\mathrm{mg} / \mathrm{ml} \mathrm{STa}$. Olfactory cilia, isolated and treated as described in Materials and Methods, were incubated with an odorant and various GC ligands for 2 min. Incubation was quenched with TCA, and the amount of cGMP was determined by RIA. Each ligand was dissolved in double-distilled $\mathrm{H}_{2} \mathrm{O}$ $\left(\mathrm{ddH}_{2} \mathrm{O}\right)$, kept as a stock, and diluted to the appropriate concentration immediately before use. Results are averages of duplicates representative of three separate experiments and are presented as percentage of control \pm SEM.

tested on cilia (Fig. 3). Atrial natriuretic peptide (ANP), brain natriuretic peptide (BNP), C-type natriuretic peptide (CNP), and heat-stable enterotoxin (STa) all failed to induce a cGMP response. Only IBMP elicited a response. These data suggested that odorants specifically activate a particulate guanylyl cyclase in olfactory cilia. To investigate whether cilial guanylyl cyclase activation was coupled to a G-protein, cilia were treated with the nonspecific G-protein stimulator $\mathrm{AlF}_{4}{ }^{-}$, which binds to GDP to mimic the $\gamma$-phosphate of GTP (Bigay et al., 1987; Stadel and Crooke, 1989). $\mathrm{AlF}_{4}{ }^{-}$treatment did not alter cGMP levels in cilia (data not shown); however, $\mathrm{AlF}_{4}{ }^{-}$did augment cAMP levels, consistent with previous reports (Pace et al., 1985; Sklar et al., 1986).

\section{Immunolocalization of components of the cGMP cascade to cilia}

To be relevant to signal transduction, other components (mediators and effectors) of the cGMP pathway should be present in cilia. For immunoblot analysis, cilia were solubilized, electrophoresed, transferred, and probed with affinity-purified rabbit polyclonal antibody 1139, directed against a region conserved among guanylyl cyclases (Ingi and Ronnett, 1995) (Fig. 4, lane 1). A band was detected with relative mobility corresponding to a molecular mass of $116 \mathrm{kDa}$, which is in the range of known particulate guanylyl cyclases (114-180 kDa) (Drewett and Garbers, 1994; Nakane and Murad, 1994; Fulle et al., 1995). This molecular mass is quite different from that of the soluble guanylyl cyclase $\alpha$ and $\beta$ subunits, which are 73-82 and 68-70 kDa (Drewett and Garbers, 1994; Nakane and Murad, 1994), respectively, and confirmed that cilia contain a particulate guanylyl cyclase, and the absence of soluble guanylyl cyclase in this preparation (Fig. 3).

Although most particulate guanylyl cyclases are activated by 


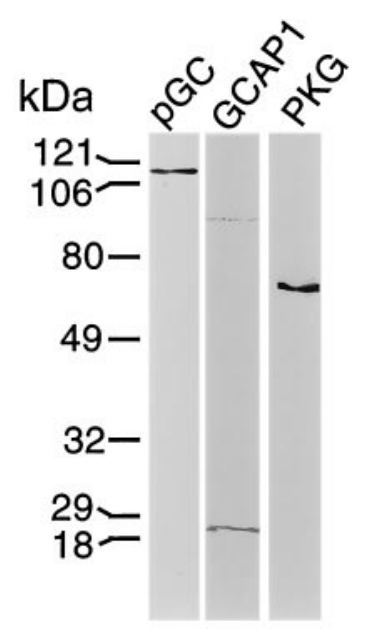

Figure 4. Expression of components of the cGMP cascade in cilia. An immunoblot of olfactory cilial proteins demonstrates the presence of particulate guanylyl cyclase, GCAP1, and PKG. Antibody 1139, which recognizes the guanylyl cyclase active site, reacts specifically with a band of relative mobility of $116 \mathrm{kDa}$ in isolated olfactory cilia. Anti-GCAP1 antibody (UW14) reacts with a band of $18 \mathrm{kDa}$ in isolated olfactory epithelium. Anti-bovine lung type I $\alpha$ PKG IgG, which can also recognize the type $\mathrm{I} \beta \mathrm{PKG}$ in a limited manner, reacts with a band of $76 \mathrm{kDa}$ in both isolated olfactory cilia and olfactory epithelium (data not shown).

extracellular ligands, the olfactory form may be more similar to retinal guanylyl cyclases, which are regulated by GCAP (Dizhoor et al., 1994; Gorczyca et al., 1994; Palczewski et al., 1994). Affinity-purified antibody directed specifically against the GCAP1 isoform identified a band of $\sim 18 \mathrm{kDa}$ in cilia (Fig. 4, lane 2), whereas anti-GCAP2 antibodies failed to detect a band (data not shown). Native GCAP1 has a molecular mass of $\sim 20 \mathrm{kDa}$, suggesting that the olfactory species is closely related to GCAP1 but may contain sequence divergence. Specificity of antibodies was verified by preabsorption with the appropriate antigen. cGMP may interact with PKG to mediate signaling events (Francis and Corbin, 1994; Yau, 1994), and immunoblot using a characterized anti-PKG antibody (Francis and Corbin, 1994) indicated that PKG is present as well (Fig. 4, lane 3). Cyclic nucleotide-gated channels and cGMP-dependent phosphodiesterases were not investigated; however, cilia contain these two proteins (Dhallan et al., 1990; Juiles et al., 1997),

To determine the cellular distribution of particulate guanylyl cyclase, GCAP1-like protein, and PKG, and to confirm that GCAP2 is essentially absent from olfactory epithelium, immunohistochemistry was performed on adult rat olfactory epithelium (Fig. 5). Particulate guanylyl cyclase immunoreactivity (IR) was most intense in the olfactory sensory cilia layer, although membranous staining was present along dendrites, cell bodies, and axons (Fig. $5 A$ ). Immunoreactivity is lost within $3 \mathrm{~d}$ of bulbectomy (Fig. $5 B$ ), indicative of its localization to ORNs. PKG-IR is also visualized in the cilial layer (Fig. 5C) and is lost with bulbectomy (Fig. 5D). In contrast, GCAP2-IR is absent from cilia (Fig. $5 E$ ) and unchanged with bulbectomy (Fig. 5F). GCAP1-IR is localized to the cilial layer (Fig. $5 G$ ), and IR is again lost after bulbectomy (Fig. $5 H$ ). Preabsorption of anti-GCAP1 antibodies with GCAP1 results in loss of signal in olfactory tissue (Fig. 5I). Thus, these components are correctly positioned in cilia to participate in odorant transduction. Interestingly, guanylyl cyclase-IR in cilia was not restricted to a subset of cells, as seen by in situ hybridization for GC-D (Fulle et al., 1995), but was uniform, suggesting that multiple particulate guanylyl cyclases may be found in ORNs.

\section{Steady-state kinetic analyses of particulate guanylyl cyclases and of the effects of GCAPs and $\mathrm{Ca}^{2+}$ on activity}

To define the number and regulation of olfactory particulate guanylyl cyclases, steady-state kinetic data were obtained. In nonstimulated cilia in low $\mathrm{Ca}^{2+}(10 \mathrm{~nm})$ buffer, Eadie-Hofstee analyses revealed two sets of apparent $K_{\mathrm{m}}$ and $V_{\max }$ values: $4.4 \pm$ $0.7 \mu \mathrm{M}$ and $1.15 \pm 0.35 \mathrm{pmol} \cdot \mathrm{mg}^{-1} \cdot \mathrm{min}^{-1}$ and $1700 \pm 100 \mu \mathrm{M}$ and $21.0 \pm 4.0 \mathrm{pmol} \cdot \mathrm{mg}^{-1} \cdot \mathrm{min}^{-1}$.

Particulate guanylyl cyclases used in visual transduction are regulated by $\mathrm{Ca}^{2+}$, which acts through GCAP class of $\mathrm{Ca}^{2+}$ binding proteins. To investigate the upstream regulation of olfactory particulate guanylyl cyclase, cGMP was measured under several conditions (Table 1). Olfactory cilia were incubated at low (10 nM) and high $(10 \mu \mathrm{M}) \mathrm{Ca}^{2+}$ concentrations, at low GTP (10 $\mu \mathrm{M})$ and high GTP concentrations $(1 \mathrm{mM})$ alone, with GCAP1 or IBMP $(0.1 \mu \mathrm{M})$, or in the presence of both IBMP or GCAP1. A similar set of experimental samples tested GCAP2 in place of GCAP1, but no significant changes were seen using GCAP2 (data not shown). Under low $\mathrm{Ca}^{2+}$ and low GTP conditions, GCAP1 has no effect on cGMP formation, although IBMP and GCAP1 have modest effects. Interestingly, under high $\mathrm{Ca}^{2+}$ and low GTP concentration conditions, basal cGMP formation is reduced. Incubation with GCAP1 or IBMP alone has a significant effect on cGMP formation, whereas incubation with IBMP and GCAP1 together shows a nearly a twofold enhancement over basal activity. In contrast, there was no effect of GCAP1, IBMP, or IBMP and GCAP1 in combination when assayed at high GTP concentration (to examine the high $K_{\mathrm{m}}$ isoform of particulate guanylyl cyclase). Thus, activity of the low $K_{\mathrm{m}}$ particulate guanylyl cyclase is regulated by $\mathrm{Ca}^{2+}$ and GCAP1.

To further examine regulation, steady-state kinetic analyses were performed at variable $\mathrm{Ca}^{2+}$ concentrations in the presence or absence of GCAP1 (Table 2). Again, GCAP2 had no effect (data not shown). Neither $\mathrm{Ca}^{2+}$ nor GCAP1 affected the $K_{\mathrm{m}}$ or $V_{\text {max }}$ of the high $K_{\mathrm{m}}$ isoform. In contrast, GCAP1 had a significant effect on the $V_{\max }$ of the low $K_{\mathrm{m}}$ isoform. At low $\mathrm{Ca}^{2+}$, GCAP1 had no effect on the $K_{\mathrm{m}}$ or $V_{\text {max }}$ of the low $K_{\mathrm{m}}$ species, as would be expected because GCAP is $\mathrm{Ca}^{2+}$-dependent. However, in the presence of high $\mathrm{Ca}^{2+}$, the $V_{\max }$ increased from $1.1 \pm 0.5$ to $1.7 \pm$ $0.30 \mathrm{pmol} \cdot \mathrm{mg}^{-1} \cdot \mathrm{min}^{-1}$. Thus, the low $K_{\mathrm{m}}$ isoform of particulate guanylyl cyclase is activated by $\mathrm{Ca}^{2+}$ in a GCAP1-dependent manner.

\section{PKA-dependent phosphorylation of olfactory particulate guanylyl cyclase}

Phosphorylation also regulates membrane forms of guanylyl cyclase. Several studies demonstrated that desensitization of other guanylyl cyclases occurred as a result of either phosphorylation or dephosphorylation (Garbers, 1989; Potter and Garbers, 1992, 1994; Chinkers, 1994; Garbers and Lowe, 1994). To examine this in the olfactory system, partially purified cilial particulate guanylyl cyclase was incubated with several protein kinases in the presence or absence of activators (Fig. 6A). In the absence of exogenous kinases or activators, no endogenous phosphorylation of olfactory particulate guanylyl cyclase was seen (Fig. 6, control lane). In the presence of exogenous PKA, olfactory particulate guanylyl cyclase is phosphorylated ( $P K A$ lane), and phosphorylation was further increased when cAMP was added with PKA (PKA+cAMP lane). In the presence of a specific PKA inhibitor, 
Figure 5. Immunolocalization of components of cGMP in olfactory epithelium. Immunoreactivity was assessed in controls $(C t l)(A, C, E, G$, and $I)$ and in 3 d postbulbectomy $(B x)(B, D, F$, and $H)$ tissues for guanylyl cyclase $(G C)(A, B), P K G(C$, $D), G C A P 2(E, F)$, and $G C A P 1(G-I)$. Anti-GCAP1 antibodies were preincubated with GCAP1 in $I$. GC, GCAP1, and PKG expression localizes to cilia, whereas GCAP2 cannot be detected. In addition, $\mathrm{GC}$ is also found in cell bodies and axonal regions. $C L$, Cilial layer; $O R N$, olfactory receptor neurons; $A x$, axons.

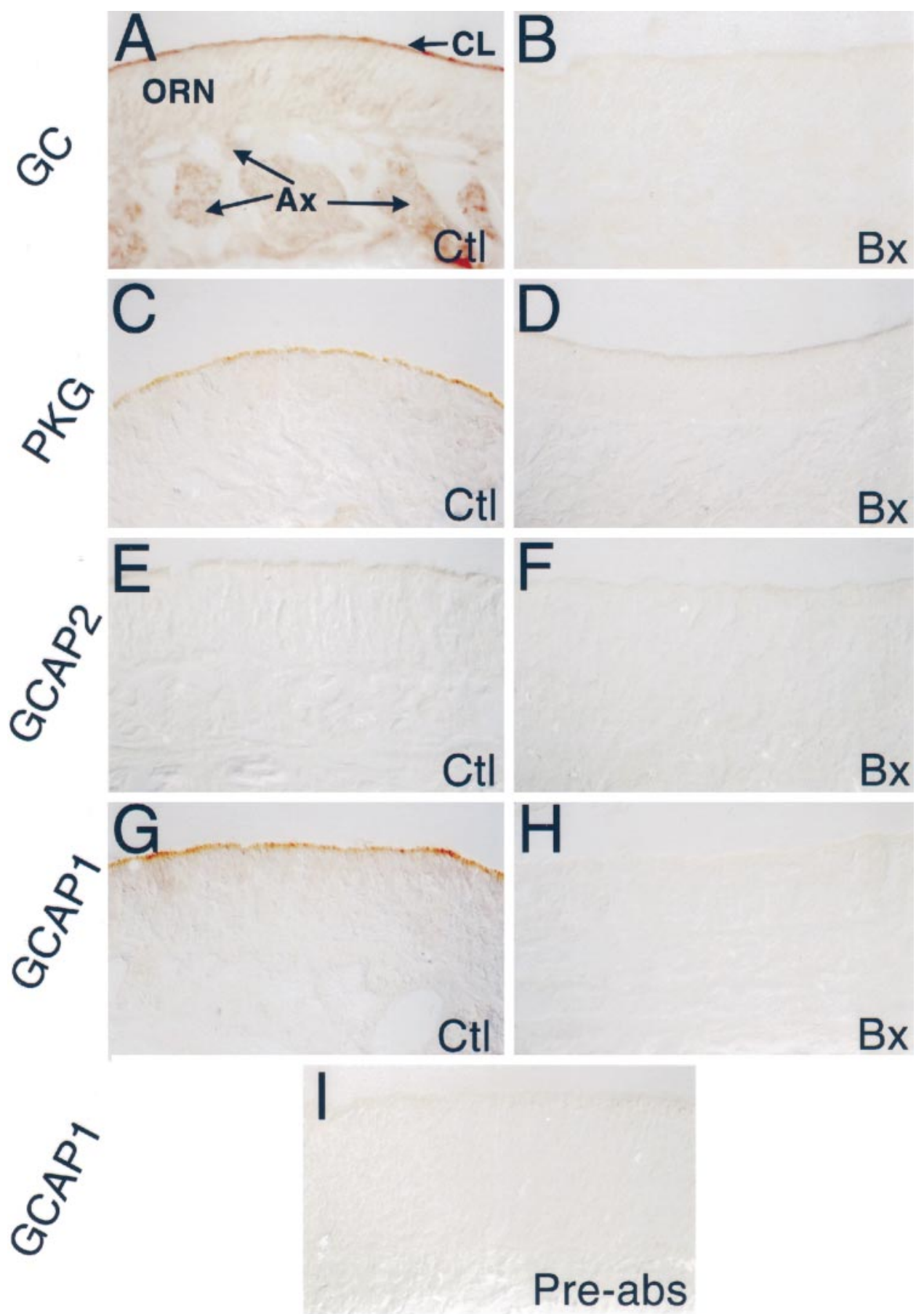

KT 5720, phosphorylation of olfactory particulate guanylyl cyclase was inhibited. In contrast, when either PKG, PKC, or $\mathrm{Ca}^{2+}$ / calmodulin-dependent protein kinase was used in the presence of their activators, no phosphorylation of particulate guanylyl cyclase was obtained (last three lanes). These kinases were shown to be active at the concentrations used by their ability to phosphorylate known substrates (data not shown). Thus, olfactory particulate guanylyl cyclase appears to be most readily phosphorylated by PKA.

To determine the functional consequences of phosphorylation, the effect of PKA on olfactory particulate guanylyl cyclase activity was determined by measuring cGMP levels (Fig. 6B). Both high and low GTP concentrations were used to determine which isoform was affected. PKA had no effect on the activity of the high $K_{\mathrm{m}}$ form, but it significantly inhibited the activity of the low $K_{\mathrm{m}}$ form.

\section{Effect of odorant on phosphorylation of particulate guanylyl cyclase}

Although we demonstrated that PKA can decrease cGMP synthesis and phosphorylate cilial particulate guanylyl cyclase (Fig. 6), we wished to determine whether odorant could directly affect phosphorylation of this enzyme. Cilia were incubated with PKA, odorant, and PKA inhibitor alone and in combination before solubilization and SDS-PAGE and quantitation (Fig. 7). The addition of PKA alone produced modest 


\begin{tabular}{|c|c|c|}
\hline \multirow[b]{2}{*}{ Condition $^{a}$} & \multicolumn{2}{|c|}{$\begin{array}{l}\text { cGMP formation }{ }^{b} \\
(\% \text { of control } \pm \text { SEM })\end{array}$} \\
\hline & Low calcium ${ }^{c}$ & High calcium $^{d}$ \\
\hline \multicolumn{3}{|l|}{ Low $(\mathrm{GTP})^{e}$} \\
\hline Control & $100.04 \pm 3.50$ & $82.01 \pm 7.80$ \\
\hline GCAP1 & $98.66 \pm 3.89$ & $118.29 \pm 13.20$ \\
\hline IBMP & $125.43 \pm 9.60$ & $137.81 \pm 14.67$ \\
\hline IBMP + GCAP1 & $116.19 \pm 7.95$ & $152.30 \pm 18.53$ \\
\hline \multicolumn{3}{|l|}{ High $(\mathrm{GTP})^{f}$} \\
\hline Control & $100.01 \pm 2.83$ & $86.96 \pm 9.67$ \\
\hline GCAP1 & $88.38 \pm 5.60$ & $75.61 \pm 5.56$ \\
\hline IBMP & $96.23 \pm 5.67$ & $72.68 \pm 4.26$ \\
\hline IBMP + GCAP1 & $92.67 \pm 4.57$ & $79.15 \pm 9.39$ \\
\hline
\end{tabular}

${ }^{a}$ Olfactory cilia were preincubated in buffer containing IBMX for 15 min and incubated for $2 \mathrm{~min}$ in reaction buffer, as described in Materials and Methods.

${ }^{b}$ cGMP formation was measured by RIA, as described in Materials and Methods, and is presented as the average of at least six determinations \pm SEM.

${ }^{c}$ Low calcium is $10 \mathrm{~nm}$, as determined by $\mathrm{pCa}$ measurements, as described in Materials and Methods.

${ }^{d}$ High calcium is $10 \mu \mathrm{M}$, as determined by pCa measurements.

${ }^{e}$ Low GTP concentration is $10 \mu \mathrm{M}$.

${ }^{f}$ High GTP concentration is $1 \mathrm{~mm}$.

Table 2. Steady-state kinetic analysis of the effect of calcium and GCAP1 on cGMP production

\begin{tabular}{|c|c|c|}
\hline Condition $^{a}$ & $K_{\mathrm{m}}(\mu \mathrm{M} \pm \mathrm{SEM})$ & $\begin{array}{l}V_{\max }(\mathrm{pmol} \cdot \\
\cdot \min ^{-1} \pm \mathrm{SEl} \\
\end{array}$ \\
\hline \multicolumn{3}{|l|}{$\begin{array}{l}\text { High calcium } \\
\quad\left(\text { low } K_{\mathrm{m}}\right)\end{array}$} \\
\hline Control & $7.0 \pm 2.0$ & $1.15 \pm 0.05$ \\
\hline + GCAP1 & $9.5 \pm 1.5$ & $1.70 \pm 0.30^{c}$ \\
\hline \multicolumn{3}{|l|}{ (high $K_{\mathrm{m}}$ ) } \\
\hline Control & $1850 \pm 550$ & $17.2 \pm 0.3$ \\
\hline + GCAP1 & $2000 \pm 400$ & $19.7 \pm 6.4$ \\
\hline \multicolumn{3}{|l|}{$\begin{array}{l}\text { Low calcium }^{d} \\
\quad\left(\text { low } K_{\mathrm{m}}\right)\end{array}$} \\
\hline Control & $4.4 \pm 0.7$ & $1.15 \pm 0.35$ \\
\hline + GCAP1 & $4.9 \pm 0.4$ & $1.21 \pm 0.20$ \\
\hline \multicolumn{3}{|l|}{ (high $K_{\mathrm{m}}$ ) } \\
\hline Control & $1700 \pm 100$ & $21.0 \pm 4.0$ \\
\hline + GCAP1 & $2000 \pm 500$ & $25.1 \pm 7.9$ \\
\hline
\end{tabular}

$\overline{{ }^{a} \text { Olfactory cilia were preincubated in buffer containing IBMX for } 15 \mathrm{~min} \text { and }}$ incubated for $2 \mathrm{~min}$ in reaction buffer, as described in Materials and Methods.

${ }^{b}$ High calcium is $10 \mu \mathrm{M}$, as determined by pCa measurements as described in Materials and Methods.

${ }^{c}$ Statistically significant difference $(p<0.05)$.

${ }^{d}$ Low calcium is $10 \mathrm{~nm}$, as determined by pCa measurements.

phosphorylation of the $116 \mathrm{kDa}$ band, the band that was immunoreactive with anti-guanylyl cyclase antibodies. Phosphorylation was blocked by PKA inhibitor. Odorant also caused minimal yet statistically significant increased phosphorylation. However, simultaneous addition of PKA and odorant resulted in a dramatic increase in phosphorylation, which was blocked by PKA inhibitor. These results suggest that odorants can directly increase the phosphorylation of particulate guanylyl cyclase.

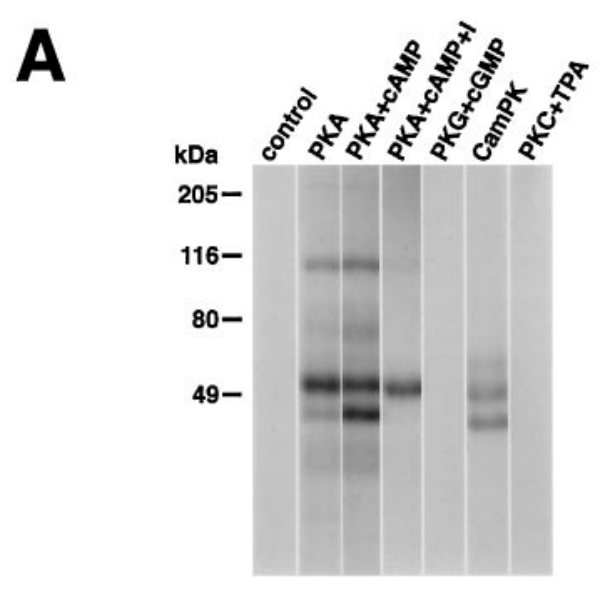

B

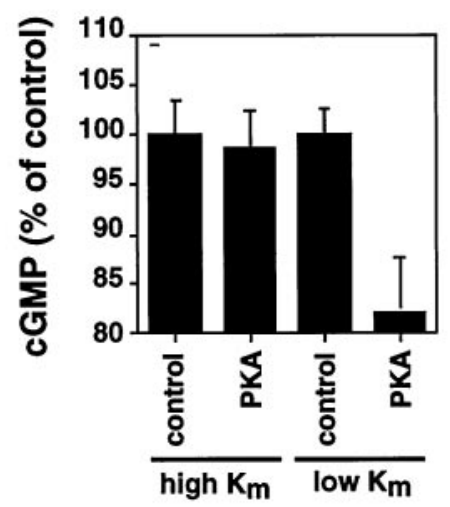

Figure 6. Phosphorylation of olfactory particulate guanylyl cyclase by protein kinases. $A$, In vitro phosphorylation of guanylyl cyclase by various protein kinases. Olfactory particulate guanylyl cyclase was solubilized and purified by a single chromatography step on a GTP-agarose column and incubated with PKA $(250 \mathrm{U} / 20 \mu \mathrm{g}), \mathrm{PKG}(300 \mathrm{U} / 1 \mu \mathrm{g}), \mathrm{Ca}^{2+} /$ calmodulin PK (CamPK, $300 \mathrm{U} / 500 \mathrm{ng}$ ), or PKC (300 U/50 ng) for $30 \mathrm{~min}$ (Promega) at $30^{\circ} \mathrm{C}$. One unit is the amount of each kinase required to incorporate 1 pmol of phosphate into the substrates of each kinase per minute. PKA was incubated in either the absence or presence of $1 \mathrm{mM} 8$-Br-cAMP. The effect of PKA-specific inhibitor was also tested. PKG was stimulated in the presence of $1 \mathrm{~mm}$ 8-Br-cGMP. With CamPK, pGC was incubated in the presence of $10 \mu \mathrm{M}$ calmodulin and $10 \mathrm{mM} \mathrm{Ca}^{2+}$. PKC was stimulated by adding $20 \mu \mathrm{g}$ of phosphatidylserine and $250 \mathrm{~nm} 12-O$-tetradecanoyl phorbol 13-acetate. $B$, Effect of PKA on particulate guanylyl cyclase activity. Purified pGC was phosphorylated by the catalytic subunit of protein kinase A for $30 \mathrm{~min}$, after which cGMP levels were determined. Guanylyl cyclase was assayed at high $(1 \mathrm{mM})$ or low $(10 \mu \mathrm{M})$ GTP concentrations to delineate high and low $K_{\mathrm{m}}$ activities. The results shown are representative of six independent experiments and presented as percentage of control \pm SEM.

\section{Effect of cGMP and PKG on cAMP levels and adenylate cyclase activity}

The slower, delayed time course of odorant-induced cGMP response, compared with the rapid and transient productions of cAMP and $\mathrm{IP}_{3}$, suggests that cGMP is not involved in odorant detection but is involved in desensitization or activity-driven responses. Adenylate cyclase is a likely target for such regulation. The effect of PKG on cAMP levels was determined in olfactory cilia in the presence of IBMX (Fig. $8 A$ ). No exogenous cGMP was added because this could obscure the results of RIA: high levels of cGMP interfere with the RIA (data not shown). Odor- 


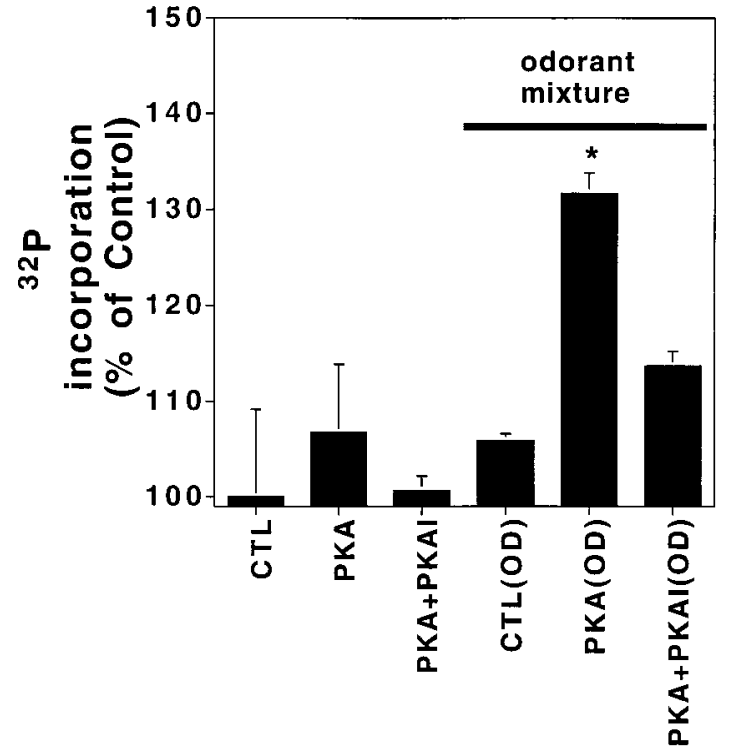

Figure 7. Effect of odorants on phosphorylation of olfactory particulate guanylyl cyclase. Cilia were preincubated in phosphorylation buffer as described in Materials and Methods. Incubation of cilia in buffer containing $\left[\gamma^{32} \mathrm{P}\right]$-ATP was performed for $30 \mathrm{~min}$ at room temperature in the presence of PKA, PKA and PKA inhibitor $(P K A+P K A I)$, odorant mixture $[C T L(O D)]$, PKA and odorant $[P K A(O D)]$, or PKA, odorant, and PKA inhibitor $[P K A+P K A I(O D)]$. At the end of incubation, reactions were quenched, solubilized, and run on SDS-PAGE. Quantitation of relative degree of phosphorylation was performed using a Personal Densitometer SI (Molecular Dynamics). Both PKA and odorant mixture alone gave a small increase in phosphate incorporation. When incubated with PKA and odorant mix together, the level of phosphorylation increased significantly $(p<0.05)$. Data shown are averages of three separate determinations.

ant alone (IBMP) had a modest effect on cAMP levels measured at this longer time of $5 \mathrm{sec}$. cAMP production was increased in the presence of PKG and IBMP. The addition of PKG inhibitor significantly diminished this effect. In the presence of IBMP, the addition of increasing concentrations of PKG resulted in a dosedependent increase in cAMP levels (Fig. 8B).

These data suggest that $\mathrm{PKG}$ increased cAMP production. However, ambient cAMP levels are the result of synthetic and hydrolytic rates. To more specifically determine the mechanism by which PKG increased cAMP levels, the effect of PKG on cilial adenylate cyclase activity was measured directly (Fig. 9). The addition of 8-Br-cGMP alone increased adenylate cyclase activity, probably because of residual protein kinases present in cilia, as demonstrated by immunoblot (Fig. 4). Odorant produced a small increase in adenylate cyclase activity, which was increased by the addition of exogenous PKG. The addition of PKG inhibitor to this mixture decreased activity. In the presence of forskolin, PKG was still able to augment adenylate cyclase activity, suggesting that adenylate cyclase was directly affected by PKG. This effect appears specific for PKG, because even high concentrations of 8-Br-cGMP (1 mM) could not substitute for PKG. These data demonstrate that cGMP can activate adenylate cyclase in a PKG-dependent manner.

\section{DISCUSSION}

These studies demonstrate the existence of at least two kinetically distinct isoforms of particulate guanylyl cyclase in olfactory cilia, of which the low $K_{\mathrm{m}}$ species is regulated by $\mathrm{Ca}^{2+}$ and a GCAP1like binding protein. The demonstration that this olfactory par-

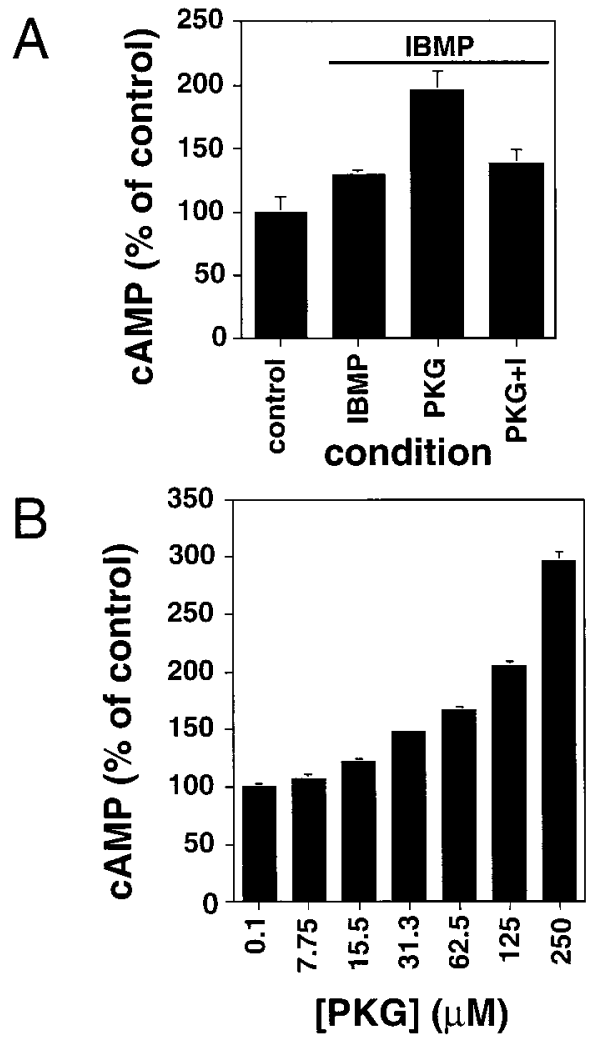

Figure 8. Effect of IBMP and PKG on cAMP levels. $A$, Effect of PKG and $\mathrm{PKG}$-specific inhibitor on odorant-induced cAMP production. IBMP $(0.1 \mu \mathrm{M})$ was applied for $2 \mathrm{~min}$ to cilia, with or without $60 \mu \mathrm{M}$ PKG and $20 \mu \mathrm{M}$ PKG inhibitor, K T5823. The isolated olfactory cilia were incubated with PKG for $15 \mathrm{~min}$ before assay at room temperature. Results are presented as percentage of control \pm SEM. $B$, Dose-dependency of cAMP production on PKG concentration in isolated rat olfactory cilia. PKG was incubated with the olfactory cilia at concentrations from 0 to $250 \mu \mathrm{M}$ in the presence of $0.1 \mu \mathrm{M}$ IBMP applied for $2 \mathrm{sec}$. To inhibit PDE activity, $0.5 \mathrm{~mm}$ IBMX was added.

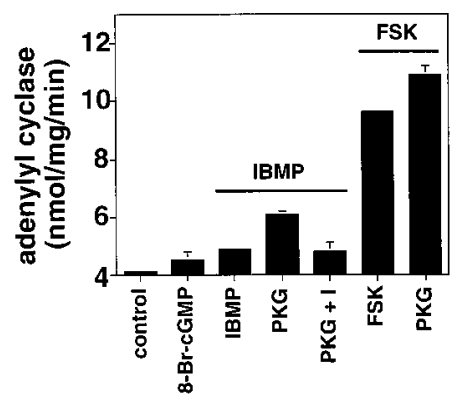

Figure 9. Effect of PKG on adenylate cyclase activity in rat olfactory cilia. IBMP $(0.1 \mu \mathrm{M})$ or forskolin $(1 \mu \mathrm{M})$ was applied for $1 \mathrm{~min}$. Incubations included $1 \mathrm{mM}$ 8-Br-cGMP, $60 \mu \mathrm{M}$ PKG, or $20 \mu \mathrm{M}$ PKG inhibitor as indicated. The isolated olfactory cilia were incubated with PKG and 8 -Br-cGMP for $15 \mathrm{~min}$ before adenylate cyclase assay at room temperature. Results are presented as specific activity \pm SEM.

ticulate guanylyl cyclase is odorant-responsive over a longer time course and modulated by PKA phosphorylation provides evidence for the involvement of this enzyme in secondary events of odorant signal transduction (Fig. 10). Odorants activate adenylate cyclase to generate cAMP, which functions in an immediate response to gate a nonspecific cation channel (the olfactory cyclic nucleotide channel, OCNC), to depolarize the ORN (Nakamura 


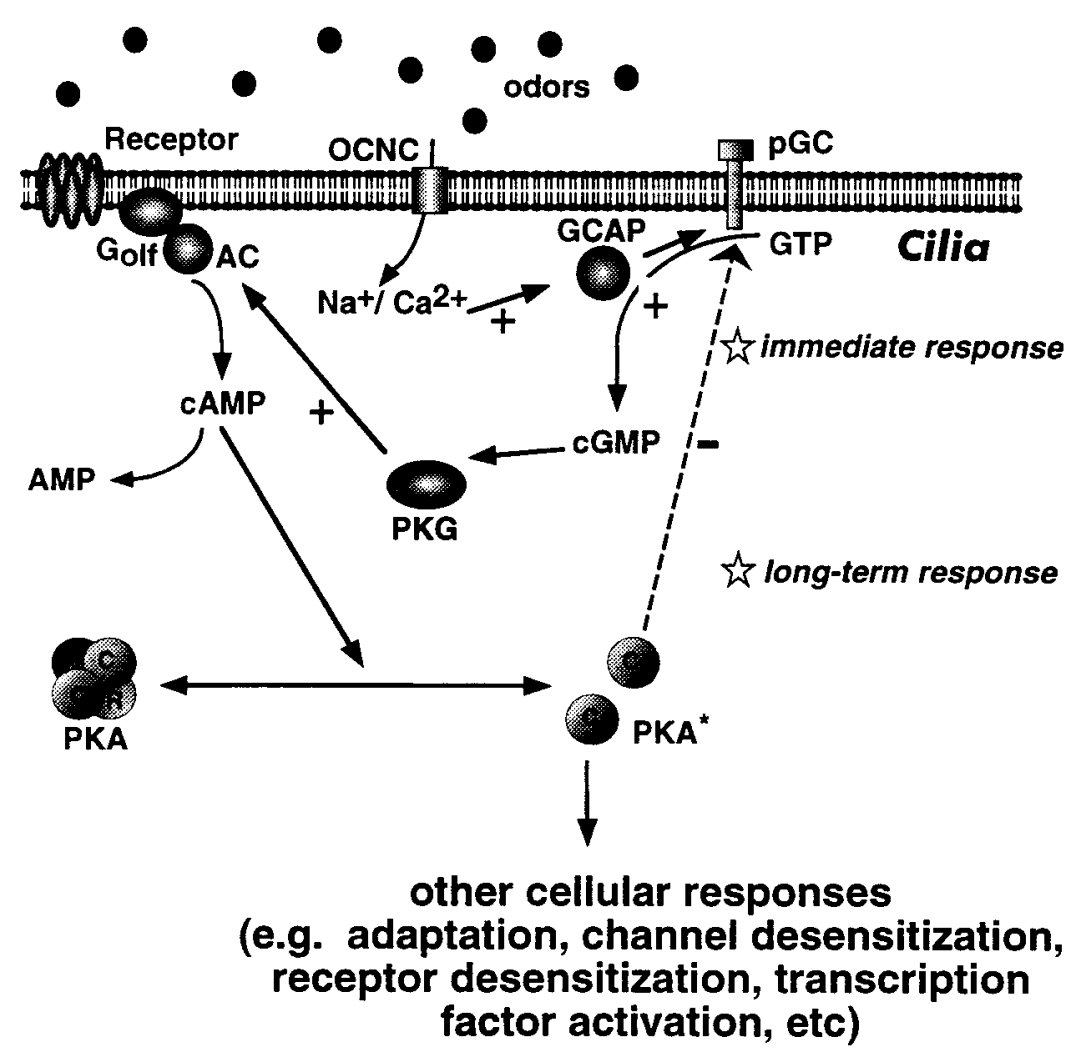

Figure 10. Proposed model for the modulation of the cAMP pathway by particulate guanylyl cyclase in ORNs. The odorant receptor, when coupled to G-protein, can stimulate adenylate cyclase, leading to an increase in intracellular cAMP and opening of the olfactory cyclic nucleotide-gated ion channels (OCNCs). Longer exposure to odorants can stimulate particulate guanylyl cyclase in cilia to produce cGMP and activate PKG, leading to a further increase in amount and duration of intracellular cAMP levels, which may serve to convert inactive forms of protein kinase $\mathrm{A}\left(P K A^{-}\right)$to active forms $\left(P K A^{*}\right)$. As part of a feedback loop, PKA can inhibit the activation of particulate guanylyl cyclase. and Gold, 1987). With a delayed time course, odorants also activate particulate guanylyl cyclase in cilia, through a $\mathrm{Ca}^{2+}$ dependent mechanism involving a GCAP1-like protein. cGMP subsequently stimulates adenylate cyclase in a PKG-dependent manner. In turn, PKA can negatively regulate particulate guanylyl cyclase, limiting cGMP production, as has been seen in other systems (Potter and Garbers, 1992, 1994).

The role and regulation of particulate guanylyl cyclase have been more elusive than those of cAMP, in part because of the fact that two vastly different forms of guanylyl cyclases exist (Yuen and Garbers, 1992). Significant insight was made in our understanding of the regulation of soluble guanylyl cyclase with the identification of its activators NO and CO (Verma et al., 1993; Dawson and Snyder, 1994). Particulate guanylyl cyclases, activated by extracellular ligands, play central roles in invertebrate fertilization (Garbers, 1991) and water regulation (Vaandrager and De Jonge, 1994), but identification of other functions and ligands has been slow. Ligand (odorant) activation of a class of particulate guanylyl cyclases has been suggested by Garbers and collaborators (Juiles et al., 1997; Yu et al., 1997). In Caenorhabditis elegans, a family of at least 29 receptors has been identified (Yu et al., 1997), whereas the number in rat is quite low (Fulle et al., 1995; Juiles et al., 1997). A limited number of particulate guanylyl cyclases have also been found to exist in ORNs on the basis of RT-PCR (Matsuoka et al., 1995). This suggests that in mammals, the binding of odorant directly to particulate guanylyl cyclase is less likely, because unrelated odorants would have the same effect.

The present data provide evidence for another mechanism of activation. Insight into the function of particulate guanylyl cyclases in sensory neurons emerged in visual transduction, where particulate guanylyl cyclase restores outer segment cGMP levels, not during binding of extracellular ligand but during activation by guanylyl cyclase activating protein (GCAP) at low $\mathrm{Ca}^{2+}$ concen- trations (Dizhoor et al., 1994; Gorczyca et al., 1994). A similar mechanism may exist for olfaction, not to restore second messenger levels but to increase cGMP in a stimulus-dependent manner to regulate downstream responses. This is suggested by the striking differences in steady-state kinetic parameters for the retinal and olfactory particulate guanylyl cyclases. In this study, we have identified at least two kinetically distinct isoforms expressed in cilia, a high $(1700 \mu \mathrm{M}) K_{\mathrm{m}}$ and a novel low $(7 \mu \mathrm{M}) K_{\mathrm{m}}$ species. The $V_{\max }$ values in the olfactory cilia are much lower than those attributed to retinal forms of particulate guanylyl cyclases (retGCs). The $V_{\max }$ of retGC expressed in 293 cells is 85 $\mathrm{pmol} \cdot \mathrm{mg}^{-1} \cdot \mathrm{min}^{-1}$, and those of GC-E and GC-F transfected into COS cells are 193 and $120 \mathrm{pmol} \cdot \mathrm{mg}^{-1} \cdot \mathrm{min}^{-1}$, respectively (Yang et al., 1995). This suggests that the olfactory enzyme is not constitutively active, as in the case of retina, but instead may be activated in response to odorants. In addition, the $K_{\mathrm{m}}$ values support this hypothesis. It is the low $K_{\mathrm{m}}$ form that is activated by $\mathrm{Ca}^{2+}$ and GCAP1; the role of the other isoform is unclear, but it may function in other cellular processes thus far suggested for cGMP, such as channel adaptation (Leinders-Zufall et al., 1996). The low $K_{\mathrm{m}}$ guanylyl cyclase does contribute to the values generated for the high $K_{\mathrm{m}}$ form; however, because the $V_{\max }$ for the high $K_{\mathrm{m}}$ guanylyl cyclase is much higher, the contribution of the low $K_{\mathrm{m}}$ species is quite small, explaining why one does not see an effect of odorant or GCAP1 on the high $K_{\mathrm{m}}$ isoform.

The olfactory GCAP either is identical to GCAP1 or is closely related in sequence. Although the olfactory GCAP isoform is quite similar (if not identical) to GCAP1, its mechanism of action is different from that in vision. In vision, retGC is activated by GCAP1 in its $\mathrm{Ca}^{2+}$-free form (Gorczyca et al., 1995). In olfaction, GCAP1 activates particulate guanylyl cyclase when bound to $\mathrm{Ca}^{2+}$. However, retGC can also be stimulated by S-100b protein in the presence of $\mathrm{Ca}^{2+}$ (Pozdnyakov et al., 1995; Duda et al., 
1996; Margulis et al., 1996), suggesting that the stimulation of guanylyl cyclase by $\mathrm{Ca}^{2+}$ in the olfactory system is not without precedent. Other $\mathrm{Ca}^{2+}$-binding proteins, such as calmodulin, appear to have no effect on the olfactory particulate guanylyl cyclase (C. Moon and G. V. Ronnett, unpublished observations).

$\mathrm{Ca}^{2+}$ may be made available to the GCAP-1-like binding protein or recoverin in olfactory cilia by a number of mechanisms, including the olfactory cyclic nucleotide-gated channel, the $\mathrm{IP}_{3}$ receptor, or other cilial $\mathrm{Ca}^{2+}$ channels. Odorants have been shown to stimulate $\mathrm{IP}_{3}$ production in cilia (Boekhoff et al., 1990, 1994; Ronnett et al., 1993), although the generality and time course of this signal remain to be established. Breer and collaborators found that a subset of odorants cause a rapid (sub-second) and limited $\mathrm{IP}_{3}$ response (Boekhoff et al., 1990), whereas we have shown a more general and slower (several seconds) $\mathrm{IP}_{3}$ signal (Ronnett et al., 1993). $\mathrm{IP}_{3}$ may not play a major role in initial odorant signaling but may play a role in secondary cellular responses.

Although adenylate cyclases are known to be regulated by a number of protein kinases (Edelman et al., 1987; Choi et al., 1993), these results indicate that PKG can also affect activity. Adenylate cyclase III is implicated in the immediate odorant response, because of its cilial localization and enriched expression in ORNs (Bakalyar and Reed, 1990), but it need not be the isoform that mediates this delayed and longer cAMP elevation. A number of other adenylate cyclases may be associated with the olfactory neuroepithelium, such as adenylate cyclase I (Xia et al., 1992; Villacres et al., 1995), which Storm and collaborators have shown to function in LTP using a knock-out model (Wu et al., 1995). A similar function for adenylate cyclase I could exist in the ORN. Although the exact site of phosphorylation by PKG is unknown, it is safe to say that PKG phosphorylates adenylate cyclase at a different site than PKA, because PKA has a different effect (inhibitory) on adenylate cyclase. In contrast to our results, Kroner et al. (1996) reported that cGMP inhibited adenylate cyclase in a PKGdependent manner. These experiments were performed using RIA, and because there can be interference in the cAMP RIA when exogenous cGMP (or an analog) is added, we performed RIA and also assayed adenylyl cyclase directly. These results confirmed our findings that cGMP activated adenylate cyclase.

The data presented herein indicate that cGMP does not participate in the initial phase of odorant transduction but does participate in secondary events. ORNs are topologically restrained, because they can perceive stimulation by odorants only at their distal sensory cilia, quite removed from the cell body. Other second messenger pathways may be recruited or involved with propagation of a small, discrete localized signal to the level of the cell body. The present study demonstrates the existence of an odorant-dependent particulate guanylyl cyclase and investigates one of the possible physiological functions it may mediate. The potentiation of the odorant-induced cAMP response by cGMP via PKG may be viewed as a secondary modulation to the initial response. Such a role is suggested by Storm and colleagues (Dittman et al., 1997). Given the highly specialized geometry of the olfactory neuron, cAMP is elevated transiently in response to odors, and only in a limited area of the olfactory cilia. Secondary cellular effects in response to odorant activation may require spatial and temporal amplification of the cAMP signal. Many studies document the importance of cAMP in neuronal differentiation and maintenance (Nagamine and Reich, 1985). As opposed to the initial odorant-dependent cAMP response, the cGMP-dependent cAMP signal may not be involved in gating ion channels but may be involved in gene expression via a
cAMP response element binding protein (CREB) (Frank and Greenberg, 1994; Sassone-Corsi, 1995). Our results suggest a novel mechanism by which to achieve this goal.

\section{REFERENCES}

Anholt RRH, Aebi U, Snyder SH (1986) A partially purified preparation of isolated chemosensory cilia from the olfactory epithelium of the bullfrog, Rana castesbeiana. J Neurosci 6:1962-1969.

Bakalyar HA, Reed RR (1990) Identification of a specialized adenylate cyclase that may mediate odorant detection. Science 250:1403-1406.

Beavo JA, Rogers NL, Crofford OB, Hardman JG, Sutherland EW, Newman EV (1970) Effects of xanthine derivatives on lipolysis and on adenosine $3^{\prime}, 5^{\prime}$-monophosphate phosphodiesterase activity. Mol Pharmacol 6:597-603.

Bigay J, Deterre P, Pfister C, Chabre M (1987) Fluoride complexes of aluminum or beryllium act on G-proteins as reversibly bound analogues of the g phosphate of GTP. EMBO J 6:2907-2913.

Boekhoff I, Tareilus E, Strotmann J, Breer H (1990) Rapid activation of alternative second messenger pathways in olfactory cilia from rats by different odorants. EMBO J 9:2453-2458.

Boekhoff I, Michel WC, Breer H, Ache BW (1994) Single odors differentially stimulate dual second messenger pathways in lobster olfactory receptor cells. J Neurosci 14:3304-3309.

Borisy FF, Ronnett GV, Cunningham AM, Juilfs D, Beavo J, Snyder SH (1991) Calcium/calmodulin activated phosphodiesterase selectively expressed in olfactory receptor neurons. J Neurosci 12:915-923.

Breer H, Boekhoff I, Tareilus E (1990) Rapid kinetics of second messenger formation in olfactory transduction. Nature 345:65-68.

Breer H, Klemm T, Boekhoff I (1992) Nitric oxide mediated formation of cyclic GMP in the olfactory system. NeuroReport 3:1030-1031.

Brune B, Schmidt K, Ullrich V (1990) Activation of soluble guanylyl cyclase by carbon monoxide and inhibition by superoxide anion. Eur J Biochem 192:683-688.

Chinkers M (1994) Targeting of a distinctive protein-serine phosphatase to the protein kinase-like domain of the atrial natriuretic peptide receptor. Proc Natl Acad Sci USA 91:11075-11079.

Choi E-J, Xia Z, Villacres EC, Storm DR (1993) The regulatory diversity of mammalian adenylyl cyclase. Curr Opin Cell Biol 5:269-273.

Dawson TM, Snyder SH (1994) Gases as biological messengers: nitric oxide and carbon monoxide in the brain. J Neurosci 14:5147-5159.

Dhallan RS, Yau KW, Schrader KA, Reed RA (1990) Primary structure and functional expression of a cyclic nucleotide-activated channel from olfactory neurons. Nature 347:184-187.

Dittman AH, Quinn TP, Nevitt GA, Hacker B, Storm DR (1997) Sensitization of olfactory guanylyl cyclase to a specific imprinted odorant in coho salmon. Neuron 19:381-389.

Dizhoor AM, Lowe DG, Olshevskaya EV, Laura RP, Hurley JB (1994) The human photoreceptor membrane guanylyl cyclase, RetGC, is present in outer segments and is regulated by calcium and a soluble activator. Neuron 12:1345-1352.

Drewett JG, Garbers DL (1994) The family of guanylyl cyclase receptors and their ligands. Endocr Rev 15:135-162.

Duda T, Goraczniak RM, Sharma RK (1996) Molecular characterization of S100A-S100B protein in retina and its activation mechanism of bovine photoreceptor guanylyl cyclase. Biochemistry 35:6263-6266.

Edelman A, Blumenthal DK, Krebs EG (1987) Protein serine/threonine kinases. Annu Rev Biochem 56:577-613.

Firestein S, Werblin FS (1989) Odor-induced membrane currents in vertebrate olfactory receptor neurons. Science 244:79-82.

Francis SH, Corbin JD (1994) Structure and function of cyclic nucleotide-dependent protein kinases. Annu Rev Physiol 56:237-272.

Frank DA, Greenberg ME (1994) CREB: a mediator of long-term memory from mollusks to mammals. Cell 79:5-8.

Fulle H-J, Vassar R, Foster DC, Yang R-B, Axel R, Garbers DL (1995) A receptor guanylyl cyclase expressed specifically in olfactory sensory neurons. Proc Natl Acad Sci USA 92:3571-3575.

Furchgott RF, Zawadzki JV (1980) The obligatory role of endothelial cells in the relaxation of arterial smooth muscle by acetylcholine. Nature 288:373-376.

Garbers DL (1989) Guanylyl cyclase, a cell surface receptor. J Biol Chem 264:9103-9106.

Garbers DL (1991) Guanylyl cyclase-linked receptors. Pharmacol Ther 50:337-345. 
Garbers DL, Lowe DG (1994) Guanylyl cyclase receptors. J Biol Chem 269:30741-30744.

Garbers DL, Koesling D, Schultz G (1994) Guanylyl cyclase receptors. Mol Biol Cell 5:1-5.

Gorczyca WA, Gray-Keller MP, Detwiller PB, Palczewski K (1994) Purification and physiological evaluation of a guanylyl cyclase activating protein from retinal rods. Proc Natl Acad Sci USA 91:4014-4018.

Gorczyca WA, Polans AS, Surgucheva IG, Subbaraya I, Baehr W, Palczewski K (1995) Guanylyl cyclase activating protein. J Biol Chem 270:22029-22036.

Gräser T, Vedernikov YP, Li DS (1990) Study on the mechanism of carbon monoxide induced endothelium-independent relaxation in porcine coronary artery and vein. Biomed Biochim Acta 49:293-296.

Hayashi F, Yamazaki A (1991) Polymorphism in purified guanylyl cyclase from vertebrate rod photoreceptors. Proc Natl Acad Sci USA 88:4746-4750.

Ingi T, Ronnett GV (1995) Direct demonstration of a physiological role for carbon monoxide in olfactory receptor neurons. J Neurosci 15:8214-8222.

Ingi T, Cheng J, Ronnett GV (1996) Carbon monoxide: an endogenous modulator of the nitric oxide-cyclic GMP signaling system. Neuron 16:835-842.

Jaworsky DE, Matsuzaki O, Borisy FF, Ronnett GV (1995) Calcium modulates the rapid kinetics of the odorant-induced cyclic AMP signal in rat olfactory cilia. J Neurosci 15:310-318.

Juiles DM, Fulle H-J, Z hao AZ, Houslay MD, Garbers DL (1997) A subset of olfactory neurons that selectively express cGMP-stimulated phosphodiesterase (PDE2) and guanylyl cyclase-D define a unique olfactory signal transduction pathway. Proc Natl Acad Sci USA 94:3388-3395.

Kawada T, Ishibash T, Sasage H, Kato K, Imai S (1994) Modification by LY83583 and methylene blue of relaxation induced by nitric oxide, glyceryl trinitrate, sodium nitroprusside and atriopeptin in aortae of the rat, guinea-pig and rabbit. Gen Pharmacol 25:1361-1371.

Koch K-W, Stryer L (1988) Highly cooperative feedback control of retinal rod guanylyl cyclase by calcium ions. Nature 334:64-66.

Kowaluk EA, Seth P, Fung HL (1992) Metabolic activation of sodium nitroprusside to nitric oxide in vascular smooth muscle. J Pharmacol Exp Ther 262:916-922.

Kroner C, Bowkhoff I, Lohmann SM, Genieser H-G, Breer H (1996) Regulation of olfactory signalling via cGMP-dependent protein kinase. Eur J Biochem 236:632-637.

Laemmli UK (1970) Cleavage of structural proteins during the assembly of the head of bacteriophage T4. Nature 227:680-685.

Leinders-Zufall T, Shepherd GM, Zufall F (1995) Regulation of cyclic nucleotide-gated channels and membrane excitability in olfactory receptor cells by carbon monoxide. J Neurophysiol 74:1498-1508.

Leinders-Zufall T, Shepherd GM, Zufall F (1996) Modulation by cyclic GMP of the odour sensitivity of vertebrate olfactory receptor cells. Proc R Soc B Biol Sci 263:803-811.

Mahanthappa NK, Schwarting GA (1993) Peptide growth factor control of olfactory neurogenesis and neuron survival in vitro: roles of EGF and TGF-Bs. Neuron 10:293-305.

Maines MD (1988) Heme oxygenase: function, multiplicity, regulatory mechanisms, and clinical applications. FASEB J 2:2557-2568.

Margulis A, Pozdnyakov N, Sitaramayya A (1996) Activation of bovine photoreceptor guanylyl cyclase by S100 proteins. Biochem Biophys Res Commun 218:243-247.

Matsuoka I, Mori T, Sto T, Sakai M, Kurihara K (1995) Identification of novel guanylyl cyclases from chemosensory tissues of rat and cattle. Biochem Biophys Res Commun 216:242-248.

McNaughton PA (1990) Light response of vertebrate photoreceptors. Physiol Rev 70:847-883.

Murad F (1994) Regulation of cytosolic guanylyl cyclase by nitric oxide: the NO-cyclic GMP signal transduction system. Adv Pharmacol 26:1933.

Nagamine Y, Reich E (1985) Gene expression and cAMP. Proc Natl Acad Sci USA 82:4606-4610.

Nakamura T, Gold GH (1987) A cyclic-nucleotide gated conductance in olfactory receptor cilia. Nature 325:442-444.

Nakane M, Murad F (1994) Cloning of guanylyl cyclase isoforms. Adv Pharmacol 25:7-18

Otto-Bruc A, Farris RN, Haeseleer F, Huang J, Buczylko J, Suggucheva I, Baehr W, Milam AH, Palczewski K (1997) Localization of guanylyl cyclase-activating protein 2 in mammalian retinas. Proc Natl Acad Sci USA 94:4727-4732.

Pace U, Hanski E, Salomon Y, Lancet D (1985) Odorant-sensitive adenylate cyclase may mediate olfactory reception. Nature 316:255-258.
Palczewski K, Subbaraya I, Gorczyca WA, Helekar BS, Ruiz CC, Ohguro H, Huang J, Zhao X, Crabb JW, Johnson RS, Walsh KA, Gray-Keller MP, Detwiler PB, Baehr W (1994) Molecular cloning and characterization of retinal photoreceptor guanylyl cyclase-activating protein. Neuron 13:395-404.

Potter LR, Garbers DL (1992) Dephosphorylation of the guanylyl cyclase-A receptor causes desensitization. J Biol Chem 267:14531-14534

Potter LR, Garbers DL (1994) Protein kinase C-dependent desensitization of the atrial natriuretic peptide receptor is mediated by dephosphorylation. J Biol Chem 269:14636-14642.

Pozdnyakov N, Yoshida A, Cooper NG, Margulis A, Duda T, Sharma RK, Sitaramayya A (1995) A novel calcium-dependent activator of retinal rod outer segment membrane guanylyl cyclase. Biochemistry 34:14279-14283.

Rhein LD, Cagan RH (1980) Biochemical studies of olfaction: isolation, characterization and odorant binding activity of cilia from rainbow trout olfactory rosettes. Proc Natl Acad Sci USA 77:4412-4416.

Ronnett GV, Hester LD, Snyder SH (1991) Primary culture of neonatal rat olfactory neurons. J Neurosci 11:1243-1255.

Ronnett GV, Cho H, Hester LD, Wood SF, Snyder SH (1993) Odorants differentially enhance phosphoinositide turnover and adenylate cyclase in olfactory receptor neuronal cultures. J Neurosci 13:1751-1758.

Roskams AJ, Bredt DS, Dawson TM, Ronnett GV (1994) Nitric oxide mediates the formation of synaptic connections in developing and regenerating olfactory receptor neurons. Neuron 13:289-299.

Salomon Y (1979) Adenylate cyclase assay. Adv Cyclic Nucleotide Res $10: 31-54$.

Sassone-Corsi P (1995) Transcription factors responsive to cAMP. Annu Rev Cell Biol 11:355-377.

Schmidt HHHW (1992) NO, CO and OH endogenous soluble guanylyl cyclase-activating factors. FEBS Lett 307:102-107.

Sklar PB, Anholt RRH, Snyder SH (1986) The odorant-sensitive adenylate cyclase of olfactory receptor neurons. J Biol Chem 261:15538-15543.

Stadel JM, Crooke ST (1989) Aluminofluoride action on G-proteins of the adenylate cyclase system is not different from that on transducin. J Biochem 258:931-933.

Steiner JP, Dawson TM, Fotuhi M, Glatt CE, Snowman AM, Cohen N, Snyder SH (1992) High brain densities of the immunophilin FKBP colocalized with calcineurin. Nature 358:584-587.

Sun MK, Reis DJ (1992) Evidence nitric oxide mediates the vasodepressor response to hypoxia in sino-denervated rats. Life Sci 50:555-565.

Sun Y, Rotenberg MO, Maines MD (1990a) Developmental expression of heme oxygenase isozymes in rat brain. Two H0-2 mRNAs are detected. J Biol Chem 265:8212-8217.

Sun Y, Rotenberg MO, Maines MD (1990b) Developmental expression of heme oxygenase isozymes in rat brain. J Biol Chem 265:8212-8217.

Towbin H, Staehelin T, Gorden J (1979) Electrophoretic transfer of proteins from polyacrylamide gels to nitrocellulose sheets: procedure and some applications. Proc Natl Acad Sci USA 76:4350-4354.

Vaandrager AB, De Jonge HR (1994) Effect of cyclic GMP on intestinal transport. Adv Pharmacol 26:253-283.

Verma A, Hirsch DJ, Glatt CE, Ronnett GV, Snyder SH (1993) Carbon monoxide: a putative neural messenger. Science 259:381-384.

Villacres EC, Wu Z, Hua W, Nielsen MD, Watters JJ, Yan C, Beavo J, Storm DR (1995) Developmentally expressed $\mathrm{Ca}^{2+}$-sensitive adenylate cyclase activity is disrupted in the brains of type I adenylate cyclase mutant mice. J Biol Chem 270:14352-14357.

Wong SKF, Garbers DL (1992) Receptor guanylyl cyclases. J Clin Invest 90:299-305.

Wu Z-L, Thomas SA, Villacres EC, Xia A, Simmons ML, Chavkin C, Palmiter RD, Storm DR (1995) Altered behavior and long-term potentiation in type I adenylate cyclase mutant mice. Proc Natl Acad Sci USA 92:220-224.

Xia Z, Choi E-J, Wang F, Storm DR (1992) The type III calcium/ calmodulin-sensitive adenylate cyclase is not specific to olfactory sensory neurons. Neuroscience 144:169-173.

Yang R-B, Foster DC, Garbers DL, Fulle H-J (1995) Two membrane forms of guanylyl cyclase found in the eye. Proc Natl Acad Sci USA 92:602-606.

Yau K-W (1994) Cyclic nucleotide-gated channels: an expanding new family of ion channels. Proc Natl Acad Sci USA 91:3481-3483.

Yu S, Avery L, Baude E, Garbers DL (1997) Guanylyl cyclase expression in specific sensory neurons: a new family of chemosensory receptors. Proc Natl Acad Sci USA 94:3384-3387.

Yuen PST, Garbers DL (1992) Guanylyl cyclase-linked receptors. Annu Rev Neurosci 15:193-225. 